\title{
Transmission of Near-Infrared Energy by Some Two- and Three-Component Glasses ${ }^{1,2}$
}

\author{
Jack M. Florence, Francis W. Glaze, and Mason H. Black
}

\begin{abstract}
Most silicate glasses have a region of absorption for radiant energy at wavelengths longer than 2.7 microns. This absorption has been found to be caused by the presence of water and $\mathrm{CO}_{2}$ in the glass. Means for removing much of this absorption from some glasses have been developed. Also, it has been found that glasses containing lead oxide or barium oxide, or combinations of the two, do not appear to retain as much water as most other glasses. A soda-lead oxide-silica glass and a barium oxide-lead oxide-silica glass with high transmission for near-infrared energy have been developed.
\end{abstract}

\section{l. Introduction}

The National Bureau of Standards, at the request of the Department of the Navy, Bureau of Ships, has been making a study of the relationship between the transmission of infrared energy and the composition of various glasses. The first report of this work $[1]^{3}$ discussed some of the common two-component systems. This report describes a study of three-component silica glasses that have been found to have a high transmission in the near-infrared region of the spectrum, as well as some work on two-component glasses not previously reported. The preparation of these glasses has been outlined in a previous publication [1].

A study of simple glasses [1,2] has shown that certain characteristic bands, or regions, of absorption of infrared energy can be associated with certain ions or groups in the glass. The wavelengths at which these bands occur may vary slightly for different compositions, but the absorption bands for certain molecular vibrations have been identified by comparison with those of the single compounds. A list of the vibrating groups and the wavelengths of their absorption bands have been given in a previous paper [2].

If a glass of high infrared transmission is desired, these ions, or groups, must be avoided. However, it is difficult to select a composition that is free of material that absorbs infrared energy and still have a glass that can be cooled from the molten state without crystallization. In the case of silicate glasses where the $\mathrm{SiO}_{4}$ tetrahedron is one of the absorbing groups, decreasing the percentage of $\mathrm{SiO}_{2}$ is beneficial, as can be seen from the patent of Dusing [3]. Also, Weyl [4] has recommended the formation of an unsymmetrical structure by means of unbalanced forces on the $\mathrm{Si}-\mathrm{O}$ bond, thereby decreasing the intensity of the absorption band. It is believed that the increased transmission at $3.8 \mu$ in glasses of high lead oxide content may be caused by covalent bonding of the $\mathrm{Pb}^{++}$ion to the oxygen of two $\mathrm{SiO}_{4}$ tetrahedrons [5]. The size of the $\mathrm{Pb}$ and $\mathrm{Ba}$ atoms may be such that the symmetry of the $\mathrm{SiO}_{4}$ tetrahedron is modified.

${ }_{1}$ Presented at the Fiftieth Annual Meeting of the American Ceramic Society, Chicago, Ill., A pril 27,1948.

2 This project was supported by the Department of the Navy, Bureau of Ships

3 Figures in brackets indicate the literature references at the end of this paper.
Roman, Marboe, and Weyl [6] have shown that samples of powdered glass treated with barium or lead ions absorb less moisture when exposed to high humidities than do untreated samples. Probably a similar condition exists in glasses containing barium or lead oxide, which results in the retention of less water in the glass matrix. If this is true, it would explain the increased transmission of simple glasses containing these oxides.

\section{Near-Infrared Transmission}

\subsection{Transmission of binary glasses}

A binary glass, not previously reported, is one from the barium oxide-silica system. One glass (No. 9 ), containing 47 percent of $\mathrm{BaO}$ and 53 percent of $\mathrm{SiO}_{2}$, was prepared. This composition is near the eutectic composition reported by Eskola [7]. Because of its high liquidus temperature $\left(1,374^{\circ} \mathrm{C}\right)$, this composition was difficult to melt with the equipment available. However, by quenching the glass, a sample free from crystalline material was obtained. The spectral transmittance curve of this glass (fig. 1) shows the start of a water absorption band at about $2.7 \mu$. This curve is a good illustration of the continuous or overlapping absorption regions wherein the individual bands are, for all practical purposes, completely masked.

A lead oxide-silica glass (No. 10, table 1) was prepared by the usual melting procedure and its transmittance measured. Part of this same melt was then remelted under reduced pressure in a high-frequency furnace. The transmittance curve of this second sample (fig. 2) shows an improvement in the region of 2.7 to $4.5 \mu$.

Dry air was passed through the remainder of the above melt for 1 hour at $1,150^{\circ} \mathrm{C}$. The air used was dried by passing it through columns of sulfuric acid (sp gr 1.84) and anhydrous magnesium perchlorate. This dried air was conducted to the bottom of the melt by means of a platinum tube. At the end of the fining period, the air tube was raised slightly above the surface of the melt and the temperature was lowered to the pouring temperature $\left(1,060^{\circ} \mathrm{C}\right)$ in $1 / 2 \mathrm{hr}$. The transmittance curve (fig. 2) shows an additional improvement from 2.7 to $4.5 \mu$ over the 
TABLE 1. Glass compositions by weight percent

\begin{tabular}{|c|c|c|c|c|c|c|c|c|c|c|c|}
\hline $\begin{array}{l}\text { Glass } \\
\text { No. }\end{array}$ & $\mathrm{SiO}_{2}$ & $\mathrm{Li}_{2} \mathrm{O}$ & $\mathrm{Na}_{2} \mathrm{O}$ & $\mathrm{K}_{2} \mathrm{O}$ & $\mathrm{BeO}$ & $\mathrm{MgO}$ & $\mathrm{CaO}$ & $\mathrm{SrO}$ & $\mathrm{BaO}$ & $\mathrm{PbO}$ & $\begin{array}{l}\text { Notes on batch materials } \\
\text { used other than oxides }\end{array}$ \\
\hline 9 & 53. 0 & -... & -... & $-\ldots$ & $-\cdots$ & $-\ldots$ & -... & -..- & 47.0 & & $\mathrm{BaO}$ as $\mathrm{BaCO}_{3}$. \\
\hline 10 & 30.0 & $\cdots \cdot$ & -..- & $\cdots$ & -.- & -..- & -... & $-\cdots$ & -..- & 70.0 & \\
\hline $\begin{array}{l}11 \\
12\end{array}$ & $\cdots$ & $-\cdots$ & -... & 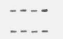 & -... & -... & -..- &..- & $+\cdots$ & 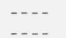 & \\
\hline 13 & 54.2 & 5.4 & (n... & $\cdots$ & $\cdots$ & (n- & $\cdots$ & ( & $\cdots$ & 40.0 & $\mathrm{Li}_{2} \mathrm{O}$ as $\mathrm{Li}_{2} \mathrm{CO}_{3}$ \\
\hline 14 & 51.3 & -..- & 10.6 & & $\cdots-$ & $\cdots-$. & $--\cdot$ & -...- & $\ldots$ & 38.1 & $\mathrm{Na}_{2} \mathrm{O}$ as $\mathrm{NaNO}_{3}$. \\
\hline $\begin{array}{l}15 \\
16\end{array}$ & $\begin{array}{l}48.6 \\
51.3\end{array}$ & 10.6 & $-\cdots$ & 15.3 & -..- & $\cdots$ & $-\cdot \cdot$ & $\cdots$ & $\cdots$ & 36.1 & $\mathrm{~K}_{2} \mathrm{O}$ as $\mathrm{KNO}_{3}$. \\
\hline 17 & $\begin{array}{l}51.3 \\
51.3\end{array}$ & $\ldots$ & 10.6 & $\cdots$ & -... & -... & $-\cdots$ & -... & -... & $\begin{array}{l}50.1 \\
38.1\end{array}$ & $\mathrm{Na}_{2} \mathrm{O}$ as NaNO \\
\hline 18 & 51.3 & --- & $\ldots$ & 10.6 & --.- & $-\cdots$ & -.-- &.-- &.-- & 38.1 & $\mathrm{~K}_{2} \mathrm{O}$ as $\mathrm{KNO}_{3}$ \\
\hline 19 & 51.3 & $\cdots$ & 10.6 & -... & .... & -... & .... & $\ldots$. & -...- & 38.1 & $\mathrm{Na}_{2} \mathrm{O}$ as $\mathrm{NaNO}_{3}$. \\
\hline 20 & $\begin{array}{l}51.3 \\
51.3\end{array}$ & $\cdots-$ & 10. 6 & $-\cdots$ & $-\cdots$ & $\cdots$ & $\cdots$ & $\cdots-$ & $\cdots$ & 38.1 & $\mathrm{Na}_{2} \mathrm{O}$ as $\mathrm{Na}_{2} \mathrm{CO}_{3}$. \\
\hline $\begin{array}{l}21 \\
22\end{array}$ & $\begin{array}{l}51.3 \\
51.3\end{array}$ & $\cdots$ & $\begin{array}{l}10.6 \\
10.6\end{array}$ &..- & -... & $\ldots$ & $\ldots$ & $\ldots$ & $\ldots$ & $\begin{array}{l}38.1 \\
38.1\end{array}$ & $\mathrm{Na}_{2} \mathrm{O}$ as $\mathrm{NaNO}_{3}$. \\
\hline $\begin{array}{l}22 \\
23\end{array}$ & 50.0 & - & 15.0 & 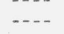 & (n... & $\ldots$ & $\ldots$ & $\ldots$ & $\cdots$ & $\begin{array}{l}38.1 \\
35.0\end{array}$ & $\begin{array}{l}\mathrm{Na}_{2} \mathrm{O} \text { as } \mathrm{Na}_{2} \mathrm{CO}_{3} . \\
\mathrm{Ca}_{2} \mathrm{O} \text {. } \\
\mathrm{NaNO}\end{array}$ \\
\hline 24 & 70.0 & .... & 15.0 & .... & -... & .... & .... & .... & .... & 15.0 & $\mathrm{Na}_{2} \mathrm{O}$ as $\mathrm{NaNO}_{3}$. \\
\hline 25 & 60.0 & .... & 15.0 & -... & -... & -..- & -... & -... & $\ldots$ & 25.0 & $\mathrm{Na}_{2} \mathrm{O}$ as NaNO${ }_{3}$ \\
\hline 26 & 50.0 & - - - & 5.0 & $\cdots$ & $\cdots$ & $\cdots$ & $\cdots$ & $\cdots$ & $\cdots$ & 45.0 & $\mathrm{Na}_{2} \mathrm{O}$ as $\mathrm{NaNO}_{3}$. \\
\hline $\begin{array}{l}27 \\
28\end{array}$ & $\begin{array}{l}60.0 \\
20.0\end{array}$ & $\cdots$ & $\begin{array}{l}5.0 \\
5.0\end{array}$ & -... & $-\cdots$ & $-\cdots \cdot$ & $\cdots-$ & $\cdots$ & $\cdots$ & $\begin{array}{l}35.0 \\
75.0\end{array}$ & $\begin{array}{l}\mathrm{Na}_{2} \mathrm{O} \text { as } \mathrm{NaNO}_{3} . \\
\mathrm{Na}_{2} \mathrm{O} \text { as } \mathrm{NaNO}_{3} .\end{array}$ \\
\hline 29 & 40.0 & ..... & 5.0 & .... & .... & .... & $\ldots$ & . & -2 & 55.0 & $\mathrm{Na}_{2} \mathrm{O}$ as $\mathrm{NaNO}_{3}$. \\
\hline 30 & 30.0 & & 5.0 & -...- & $-\cdots$ & $\cdots$ & $\cdots$ & $\cdots$ & $\cdots$ & 65.0 & $\mathrm{Na}_{2} \mathrm{O}$ as NaNO${ }_{3}$. \\
\hline 31 & 59.3 & 16.6 & -..- & $\ldots . .$. & .... & -. & 24.1 & -... & ... & .... & $\begin{array}{l}\mathrm{Li}_{2} \mathrm{O} \text { as } \mathrm{Li}_{2} \mathrm{CO}_{3} \text {, and } \mathrm{CaO} \text { as } \\
\mathrm{CaCO}_{3} \text {. }\end{array}$ \\
\hline 32 & 48.7 & 13.3 & ...- & .... & -... & .... & ...- & 38.0 & ....- & .... & $\begin{array}{l}\mathrm{Li}_{2} \mathrm{O} \text { as } \mathrm{Li}_{2} \mathrm{CO}_{3} \text {, and } \mathrm{SrO} \text { as } \\
\mathrm{Sr}\left(\mathrm{NO}_{3}\right)_{2} \text {. }\end{array}$ \\
\hline 33 & 37.1 & 7.6 & $-\cdots$ & $\ldots$ & .. & .. & -..- & $\ldots$ & 55.3 & -... & $\begin{array}{l}\mathrm{Li}_{2} \mathrm{O} \text { as } \mathrm{Li}_{2} \mathrm{CO}_{3} \text {, and } \mathrm{BaO} \text { as } \\
\mathrm{Ba}\left(\mathrm{NO}_{3}\right)_{2} \text {. }\end{array}$ \\
\hline 34 & 84.5 & 8.4 & & ...- & $\begin{array}{l}7.1 \\
6.5\end{array}$ & $\cdots-\cdot$ & $-\cdots$ & -..- & $\cdots$ & -... & $\mathrm{Li}_{2} \mathrm{O}$ as $\mathrm{Li}_{2} \mathrm{CO}_{3}$. \\
\hline $\begin{array}{l}35 \\
36\end{array}$ & $\begin{array}{l}77.5 \\
74.6\end{array}$ & $\cdots$ & $\begin{array}{l}10.0 \\
15.4\end{array}$ & $\cdots$ & -.. & 10.0 & $\cdots$ & $\cdots$ & -... & $\cdots-$ & $\begin{array}{l}\mathrm{Na}_{2} \mathrm{O} \text { as } \mathrm{Na}_{2} \mathrm{CO}_{3} \\
\mathrm{Na}_{2} \mathrm{O} \text { as } \mathrm{Na}_{2} \mathrm{CO}_{3} \text {. }\end{array}$ \\
\hline 37 & 71.8 & -... & 14.8 & -... & $\cdots$ & -..- & 13.4 & $\cdots$ & -... & $\cdots$ & $\begin{array}{l}\mathrm{Na}_{2} \mathrm{O} \text { as } \mathrm{Na}_{2} \mathrm{CO}_{3} \text {, and } \mathrm{CaO} \text { as } \\
\mathrm{CaCO}_{3} \text {. }\end{array}$ \\
\hline 38 & 64.0 & -... & 13. 2 & .... & -... & -... & $\ldots$ & 22.8 & $\ldots$ & $-\ldots$ & $\begin{array}{l}\mathrm{Na}_{2} \mathrm{O} \text { as } \mathrm{Na}_{2} \mathrm{CO}_{3} \text {, and } \mathrm{SrO} \text { as } \\
\mathrm{SrCO}_{3} \text {. }\end{array}$ \\
\hline 39 & 58.2 & -... & 12.0 & $\ldots$ & $\cdots$ & -..- & -..- & $\cdots$ & 29.8 & -..- & $\begin{array}{c}\mathrm{Na}_{2} \mathrm{O} \text { as } \mathrm{Na}_{2} \mathrm{CO}_{3} \text {, and } \mathrm{BaO} \text { as } \\
\mathrm{BaCO}_{3} \text {. }\end{array}$ \\
\hline 40 & 66.6 & $\cdots$ & .... & 20.9 & -..- & -... & 12.5 & -..- & $\cdots$ & $\cdots-$ & $\underset{\mathrm{CaCO}_{3} \text {. }}{\mathrm{K}_{2} \mathrm{O} \mathrm{CO}_{3} \text {, and } \mathrm{CaO} \text { as }}$ \\
\hline 41 & 60.3 & $-\cdot$ & $-\cdots$ & 18.9 &.- & -. & -- & 20.8 & $-\cdots$ & $-\cdots$ & $\underset{\mathrm{SrCO}_{3} \mathrm{O}}{\mathrm{K}_{2}} \mathrm{~K}_{2} \mathrm{CO}_{3}$, and $\mathrm{SrO}$ as \\
\hline 42 & 54.8 & -... & -. - & 17.2 & -... & -..- & 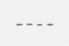 & $\cdots$ & 28.0 & ...- & 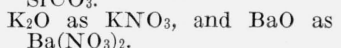 \\
\hline 43 & 40.0 & ...... & .... & -... & -..- & -... & -..- & .... & 50.0 & 10.0 & $\mathrm{BaO}$ as $\mathrm{Ba}\left(\mathrm{NO}_{3}\right)_{2}$. \\
\hline 44 & 40.0 & -... & -... & $\ldots$ & -... & -... & -... & $\ldots$ & 30.0 & 30.0 & $\mathrm{BaO}$ as $\mathrm{Ba}\left(\mathrm{NO}_{3}\right)_{2}$. \\
\hline $\begin{array}{l}45 \\
46\end{array}$ & $\begin{array}{l}32.4 \\
24.2\end{array}$ & -... & $-\cdots$ & $\cdots+-$ & 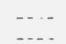 & $-\cdots$ & -..- & $-\cdots$ & $\begin{array}{l}27.6 \\
30.9\end{array}$ & $\begin{array}{l}40.0 \\
44.9\end{array}$ & $\begin{array}{l}\mathrm{BaO} \text { as } \mathrm{Ba}\left(\mathrm{NO}_{3}\right)_{2} \text {. } \\
\mathrm{BaO} \text { as } \mathrm{Ba}\left(\mathrm{NO}_{3}\right)_{2} \text {. }\end{array}$ \\
\hline 47 & 34.8 & .... & $\ldots$ & $\ldots$ & .... & $\cdots$ & 13.5 & $\ldots$ & 51.7 & .... & $\begin{array}{l}\mathrm{CaO} \text { as } \mathrm{CaCO}_{3} \text {, and } \mathrm{BaO} \text { as } \\
\mathrm{Ba}\left(\mathrm{NO}_{3}\right)_{2} \text {. }\end{array}$ \\
\hline
\end{tabular}

one obtained under reduced pressure. Although it is evident that the dry-air treatment removed more of the contaminants than did the vacuum treatment, it is believed that enough remained behind in the glass to affect the transmission.

\subsection{Transmission of three-component glasses}

\section{a. Transmission of $\mathrm{R}_{2} \mathrm{O}-\mathrm{PbO}-\mathrm{SiO}_{2}$ glasses}

Equivalent glasses (Nos. 13, 14, and 15), containing on a mole percent basis 14.3 percent of alkali, 14.3 percent of lead oxide and 71.5 percent of silica, were made to compare the effect of the different alkali metals. Transmittance curves of these glasses (fig. 3) indicate that the soda glass (No. 14) and potash glass (No. 15) have, on the average, nearly the same transmittance over the whole range of wave lengths.

Substituting $\mathrm{Li}_{2} \mathrm{O}$ and $\mathrm{K}_{2} \mathrm{O}$ for $\mathrm{Na}_{2} \mathrm{O}$ on a weightpercent basis in a glass of the composition $\mathrm{Na}_{2} \mathrm{O}$ $\mathrm{PbO}-5 \mathrm{SiO}_{2}$ gave glasses 16,17 , and 18 , the curves for which (fig. 4) show that the $\mathrm{Li}_{2} \mathrm{O}$ glass has the highest transmission for wavelengths between 3.55 and $4.5 \mu$.
Two large melts $(5,000 \mathrm{~g})$ were made of the $\mathrm{Na}_{2} \mathrm{O}$ $\mathrm{PbO}-5 \mathrm{SiO}_{2}$ composition. The source of soda in glass 19 was sodium nitrate and in glass 20 , sodium carbonate. The increased transmission of the glass from the nitrate batch (fig. 5) has also been observed for other glasses in this system. However, compositions melting at higher temperatures, such as glasses from the $\mathrm{Na}_{2} \mathrm{O}-\mathrm{BaO}-\mathrm{SiO}_{2}$ system have failed to show this improvement. If a glass made from the carbonate batch is treated with dry air, the transmission is improved until it is at least equal to that of a glass made from a nitrate batch. There is no significant change in the transmission of a glass made from the nitrate batch when it is treated with dry air (figs. 5 and 6 ).

A series of $\mathrm{Na}_{2} \mathrm{O}-\mathrm{PbO}-\mathrm{SiO}_{2}$ glasses was prepared, the compositions of which were in the region of low hygroscopicity as determined by Hubbard, Rynders, and Black [8]. The glasses of this series, which transmitted 80 percent or more at $2.9 \mu$, were in the center of this field. The complete transmittance curves of three of these glasses, 23, 24, and 25 (figs. 7, 8, and 9 ), indicate that they are similar in this respect to glass 19. The curves for five other glasses, 26, 27, 
28,29 , and 30 , with lower hygroscopicity values than the above, show a sharp decrease in transmission for wavelengths of 2.75 and longer, indicating the presence of the $\mathrm{OH}^{-}$ion (figs. 10, 11, 12, 13, and 14). Why the more hygroscopic glasses should show a higher transmission at $2.9 \mu$ than more durable glasses in the same series is not, as yet, evident.

The transmission data indicate that the $\mathrm{Na}_{2} \mathrm{O}-\mathrm{PbO}-$ $5 \mathrm{SiO}_{2}$ glass (four different melts, 19, 20, 21, and 22, are reported in this paper) has about as high a transmittance in the $2.9-\mu$ region as any composition in this system. Because of this fact, this glass has been used as the base glass for a series of experimental filters prepared at this Bureau.

\section{b. Transmission of $\mathrm{R}_{2} \mathrm{O}-\mathrm{MO}-\mathrm{SiO}_{2}$ glasses}

Glasses containing approximately 50 mole percent of $\mathrm{SiO}_{2}$ in combination with lithium oxide and one of the alkaline earths (CaO, No. 31; SrO, No. 32; and $\mathrm{BaO}$, No. 33) were made. These glasses all have about the same transmission (fig. 15).

A glass of the composition $\mathrm{Li}_{2} \mathrm{O}-\mathrm{BeO}-5 \mathrm{SiO}_{2}, \mathrm{No} .34$, has a water absorption band, but shows no $\mathrm{CO}_{3}{ }^{--}$ band at $3.5 \mu$ (fig. 16). However, there is a slight indication of a $\mathrm{CO}_{3}{ }^{-}-$band at $4.0 \mu$, and a $\mathrm{CO}_{2}$ band at $4.25 \mu$. This glass has a low coefficient of expansion $\left(5.7 \times 10^{-6}\right)$, which may suggest applications where rapid temperature fluctuations are present.

Glasses prepared with the composition $\mathrm{Na}_{2} \mathrm{O}-\mathrm{MO}-$ $5 \mathrm{SiO}_{2}$ (Be, No. 35; MgO, No. 36; CaO, No. 37; $\mathrm{SrO}$, No. 38; and $\mathrm{BaO}$, No. 39) show a trend toward decreasing water content (absorption at 2.8 to $2.9 \mu$ ) with increasing molecular weight of the alkaline earth. The beryllium, magnesium, and barium glasses show a higher absorption at $3.5 \mu\left(\mathrm{CO}_{3}{ }^{-}{ }^{-}\right)$than do the other glasses (fig. 17, 18, 19, 20, and 21). Carbonates of the alkali and the alkaline earths were used in the batch because when nitrates were used, especially with the alkaline earths of higher molecular weight, the platinum crucibles were attacked.

In the $\mathrm{K}_{2} \mathrm{O}-\mathrm{MO}-5 \mathrm{SiO}_{2}$ series, glasses were made only with $\mathrm{CaO}$ (No. 40), SrO (No. 41), and $\mathrm{BaO}$ (No. 42). The transmittance curves for these glasses (fig. 22, 23, and 24) indicate that the strontium and barium glasses contain the lowest amounts of water. The high absorption at about $3.5 \mu$ in these three glasses is doubtless caused by the carbonate ion.

\section{c. Transmission of $\mathrm{BaO}-\mathrm{PbO}-\mathrm{SiO}_{2}$ glasses}

Investigation of the $\mathrm{BaO}-\mathrm{PbO}-\mathrm{SiO}_{2}$ system lead to glass 43 with a high transmission in the 2.7- to $4.0-\mu$ region (fig. 25). 'This glass was prepared without the dry-air treatment. The transmissions of other glasses (Nos. 44, 45, and 46) from this system (fig. 26 ) indicate that the retention of water and carbonate ion varies markedly with composition.

A glass of low silica content, No. 47, was prepared from the $\mathrm{BaO}-\mathrm{CaO}-\mathrm{SiO}_{2}$ system. It had the eutectic composition reported by Eskola [9]. The transmittance curve for this glass (fig. 27) shows a strong carbonate absorption band at $3.5 \mu$, and a $\mathrm{CO}_{2}$ absorption band at $4.25 \mu$.

\section{Summary}

Two- and three-component silicate compositions containing various alkali, alkaline earth, and lead oxide combinations have been investigated to develop glasses having a high transmission of nearinfrared energy. Of the glasses studied, those containing lead or barium oxide, either alone or in combination, were found to be the most efficient infrared transmitters.

Glasses with higher infrared transmission were obtained when nitrates, rather than carbonates or hydrated materials, were used in the batch.

In general, the transmission of glasses for wavelengths longer than $2.5 \mu$ varies inversely with the hygroscopicity.

Two three-component glasses of superior transmission for infrared energy had the following compositions in weight percent: (1) $\mathrm{SiO}_{2}, 51.3$ percent; $\mathrm{PbO}, 38.1$ percent; and $\mathrm{Na}_{2} \mathrm{O}, 10.6$ percent $\left(\mathrm{Na}_{2} \mathrm{O}\right.$ $\left.\mathrm{PbO}-5 \mathrm{SiO}_{2}\right)$; (2) $\mathrm{SiO}_{2}, 40$ percent; $\mathrm{PbO}, 10$ percent; and $\mathrm{BaO}, 50$ percent.

It has been observed that, for a high transmission for wavelengths longer than $4.5 \mu$, new glass compositions free from the usual glass-formers such as $\mathrm{SiO}_{2}, \mathrm{~B}_{2} \mathrm{O}_{3}$, and $\mathrm{P}_{2} \mathrm{O}_{5}$ must be investigated.

The authors are indebted to Marshall Anderson and Nicolo Acquista of the Radiometry Section for supplying the data on the transmittances of these glasses.

\section{References}

[1] J. M. Florence, F. W. Glaze, C. H. Hahner, and R. Stair, Transmittance of near-infrared energy by binary glasses, J. Am. Ceramic Soc. 30, 328 (1948); NBS J. Research 41, 623 (1948) RP1945.

[2] J. M. Florence, C. C. Allshouse, F. W. Glaze, and C. H. Hahner, The absorptance of near-infrared energy by certain glasses, NBS J. Research 45, 121 (1950) RP2118.

[3] W. Dusing (General Electric Co.), Vitreous composition, U. S. Patent 2252495 (Aug. 12, 1941).

[4] W. A. Weyl, Private communication.

[5] J. E. Stanworth, On the structure of glass, J. Soc. Glass Tech. 32, 154 (1948).

[6] M. K. Roman, E. C. Marboe, and W. A. Weyl, The influence of heavy metal ions on the hygroscopicity of a glass surface, J. Soc. Glass Tech. 32, 260 (1948).

[7] P. Eskola, Am. J. Sci., 5th ser., 4, 345 (1922); Modified by J. W. Greig, Am. J. Sci., 5th ser., 13, 27 (1927).

[8] D. Hubbard, M. H. Black, and G. F. Rynders, Electrode function ( $\mathrm{pH}$ response), hygroscopicity, and chemical durability of $\mathrm{Na}_{2} \mathrm{O}-\mathrm{PbO}-\mathrm{SiO}_{2}$ glasses, NBS J. Research 45, 430 (1950) RP2154.

[9] P. Eskola, Am. J. Sci., 5th ser., 4, 358 (1922). 


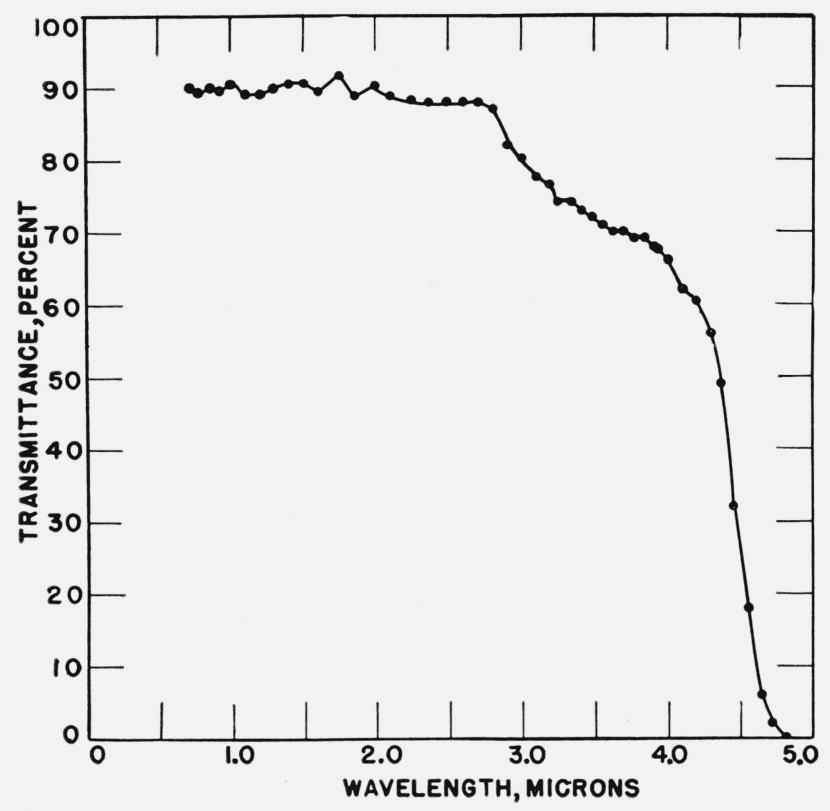

Figure 1. Infrared transmittances of barium-silicate glass $9, t=2.01 \mathrm{~mm}$.

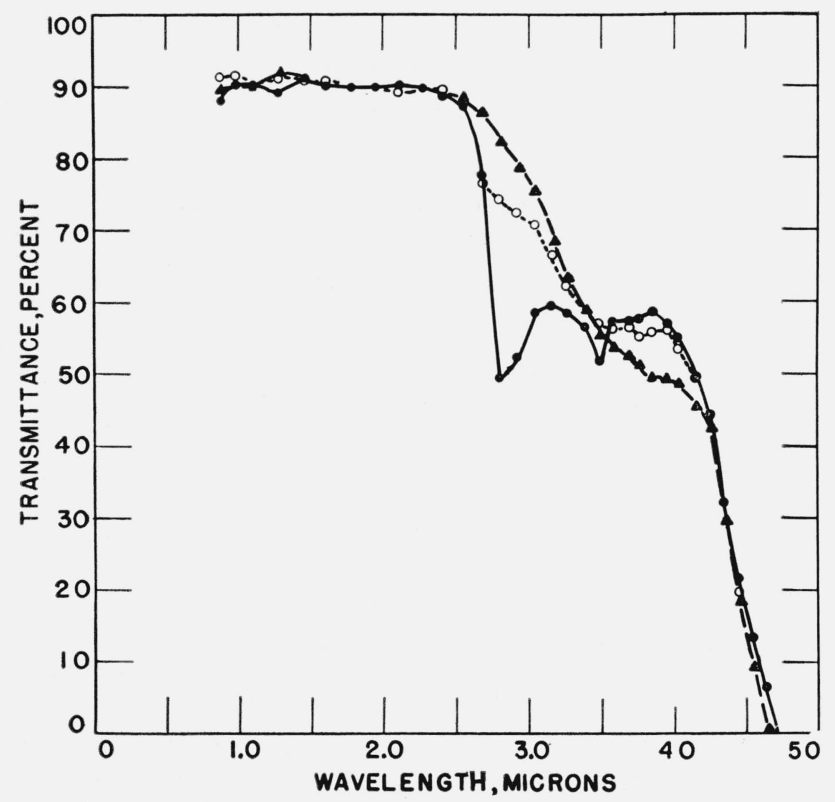

Figure 3. Infrared transmittances of alkati-lead-silicate glasses equivalent by mole percent composition.

, Glass 13 , lithium-lead-silicate, $t=1.78 \mathrm{~mm}$; $\bigcirc$, glass 14 , sodium-lead-silicate, $t=1.81 \mathrm{~mm} ; \boldsymbol{\Lambda}$, glass 15 , potassium-lead-silicate, $t=1.74 \mathrm{~mm}$.

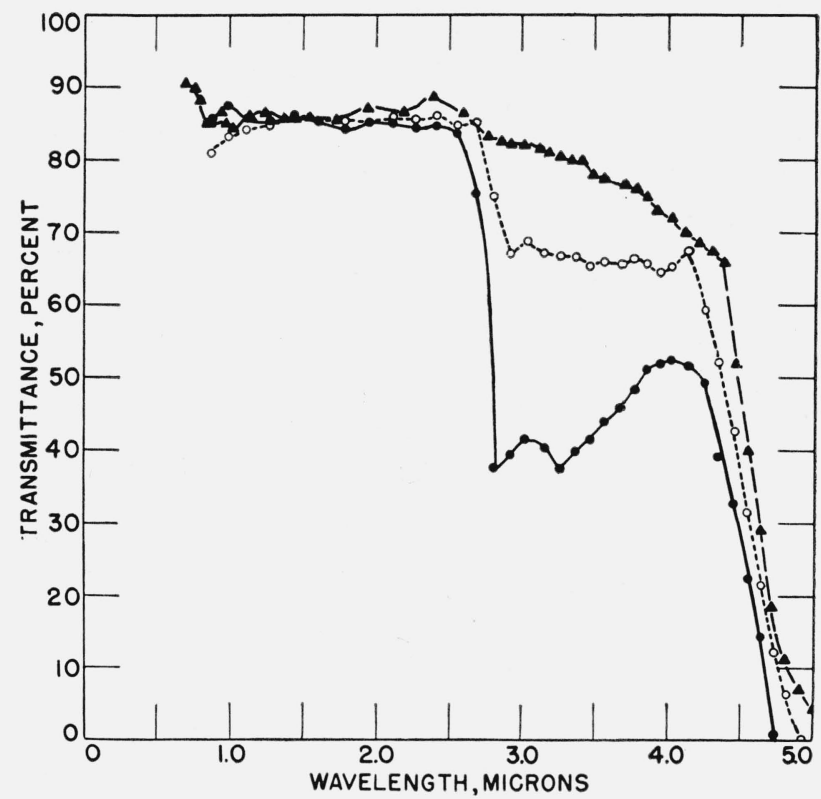

FIguRE 2. Infrared transmittances of lead-silicate glasses given special melting procedures.

Glass 10 , usual melting, $t=1.97 \mathrm{~mm}$

, glass 11 , vacuum melting, $t=1.90 \mathrm{~mm}$

$\mathbf{\Lambda}$, glass 12, air treatment, $t=2.07 \mathrm{~mm}$.

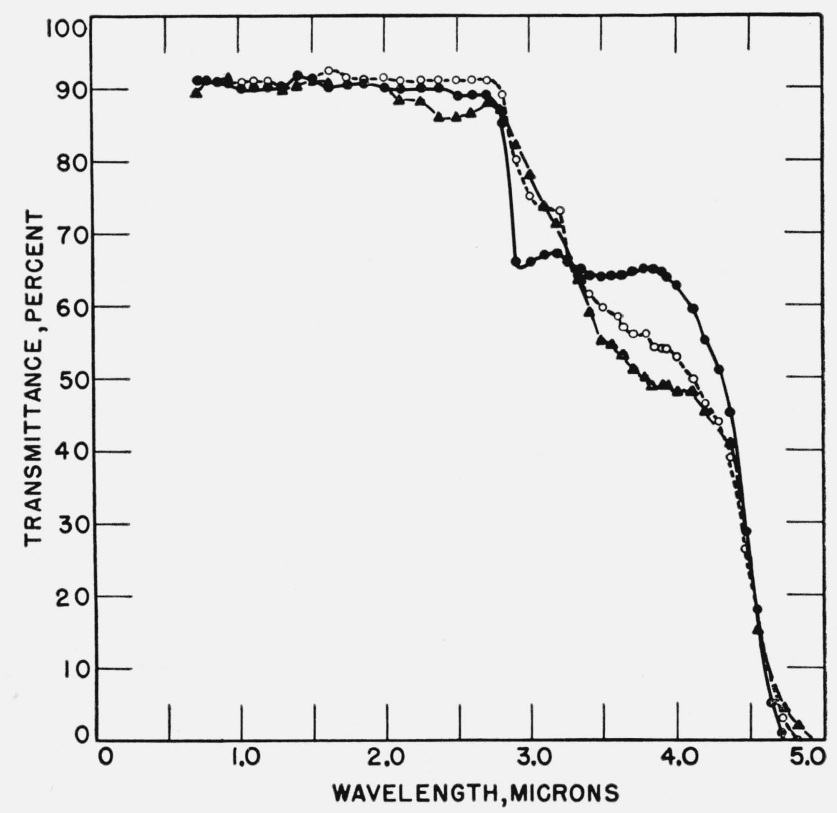

Figure 4. Infrared transmittances of alkali-lead-silicate glasses equivalent by weight percent composition.

. Glass 16 , lithium-lead-silicate glasses, $t=2.01 \mathrm{~mm}$; 0 , glass 17 , sodium-leadsilicate, $t=1.98 \mathrm{~mm} ; \boldsymbol{\Lambda}$, glass 18 , potassium-lead-silicate, $t=1.98 \mathrm{~mm}$. 


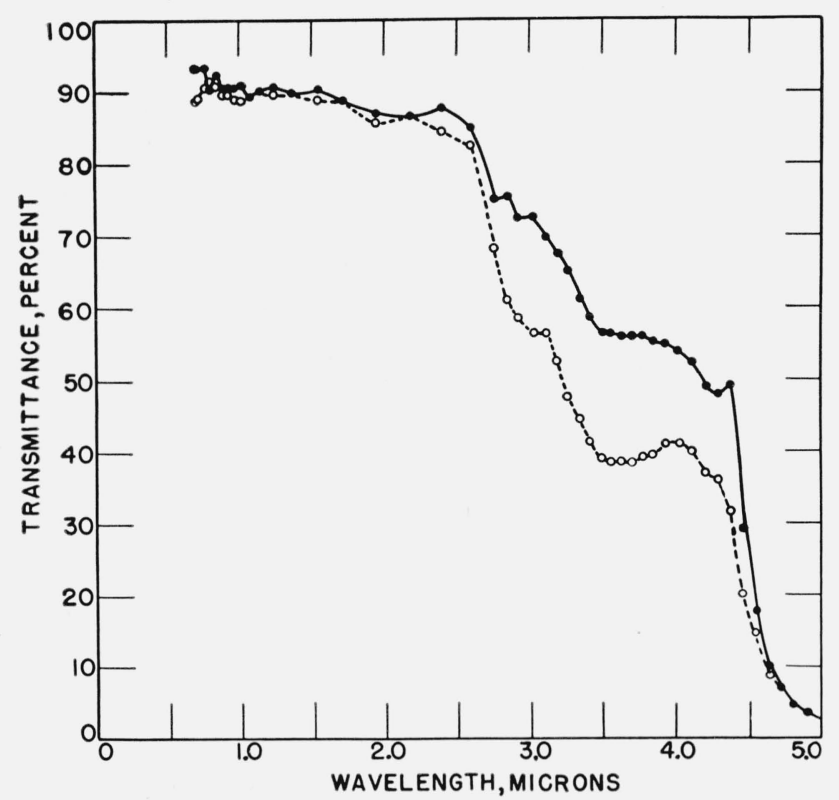

FIGURE 5. Infrared transmittances of sodium-lead-silicate glasses comparing nitrate and carbonate batches.

- Glass 19 , sodium nitrate, $t=2.07 \mathrm{~mm}$; $\bigcirc$, glass 20 , sodium carbonate, $t=$ $1.97 \mathrm{~mm}$.

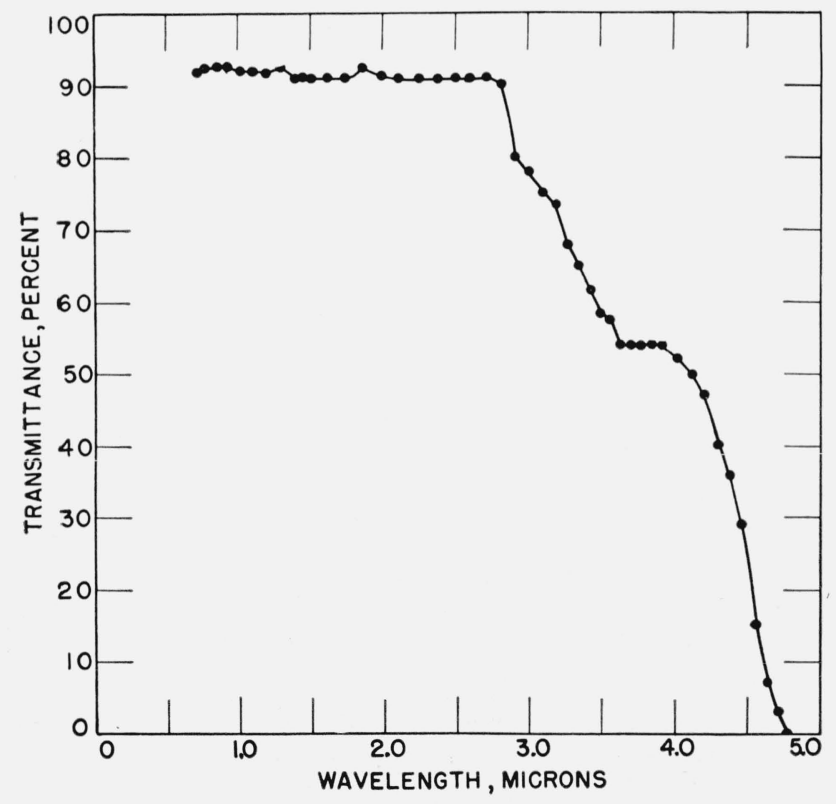

FIGURE 7. Infrared transmittances of sodium-lead-silicate glass 23 within range of compositions with high transmissivities, $t=2.02 \mathrm{~mm}$.

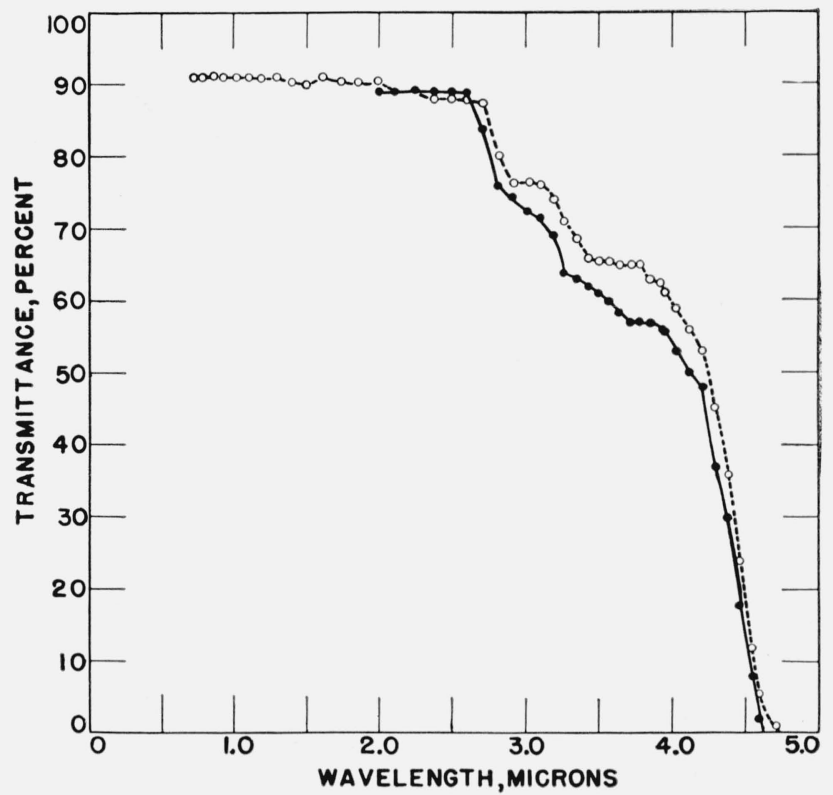

FIGURE 6. Infrared transmittances of sodium-lead-silicate glasses melted with air treatment comparing nitrate and carbonate batches.

- Glass 21 , sodium nitrate, $t=2.08 \mathrm{~mm}$; $\bigcirc$, glass 22 , sodium carbonate, $t=$ $1.87 \mathrm{~mm}$.

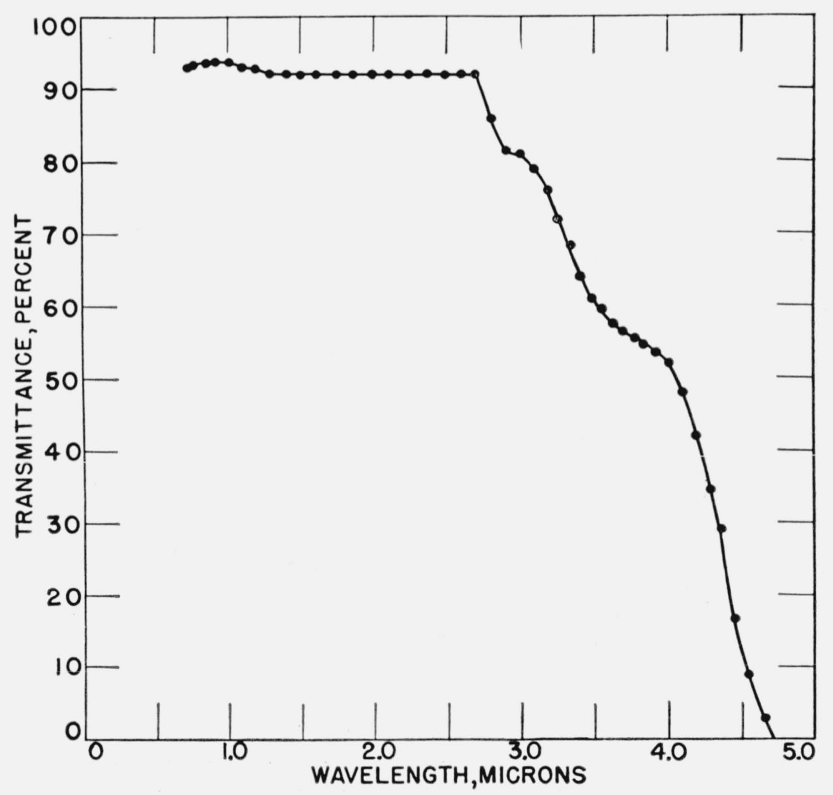

FiguRE 8. Infrared transmittances of sodium-lead-silicate glass 24 within range of compositions with high transmissivities, $t=1.82 \mathrm{~mm}$. 


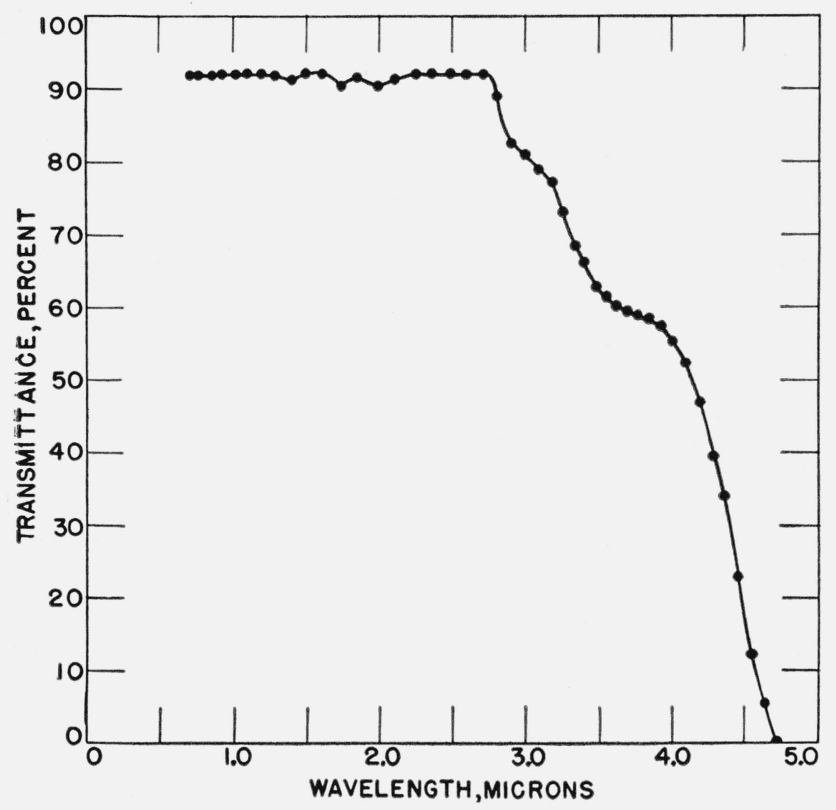

Figure 9. Infrared transmittances of sodium-lead-silicate glass 25 within range of compositions with high transmissivities, $t=1.90 \mathrm{~mm}$.

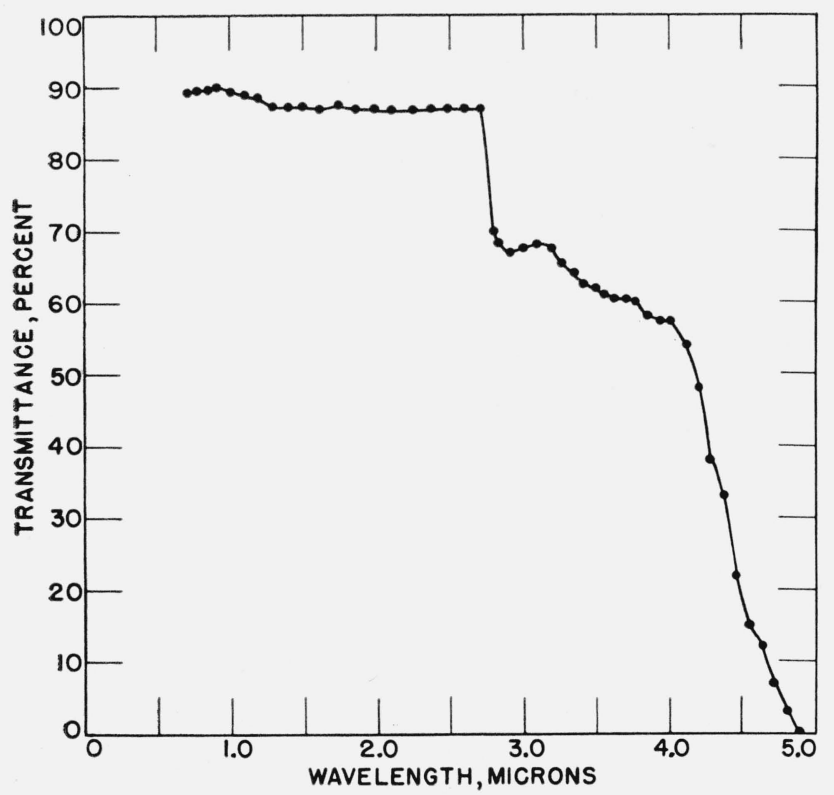

Figure 11. Infrared transmittances of sodium-lead-silicate glass 27 within range of compositions with increased absorptance at 2.9 microns, $t=1.90 \mathrm{~mm}$.

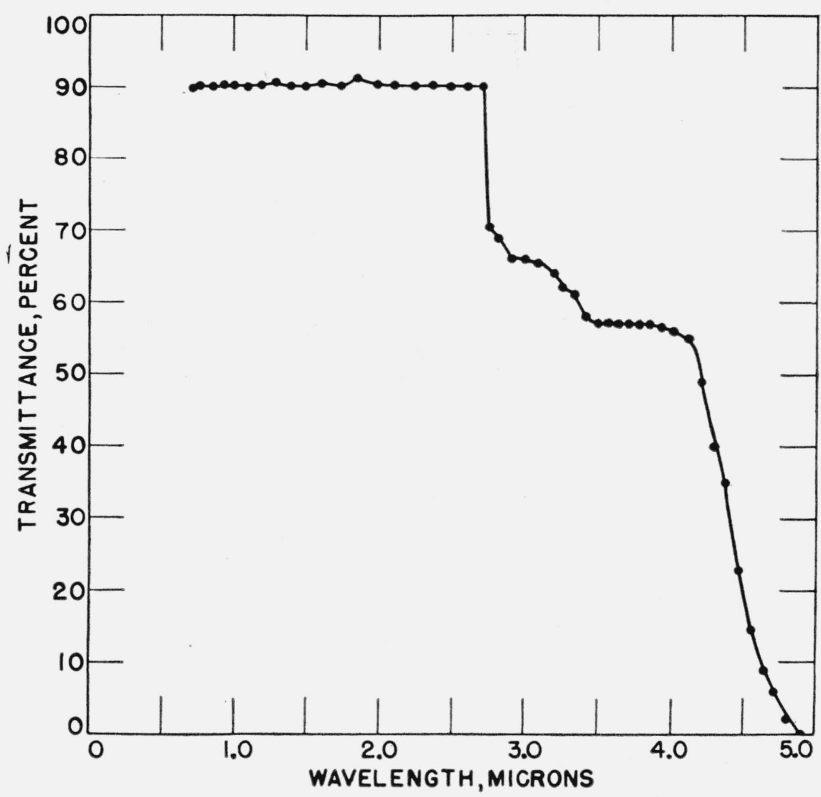

FiguRE 10. Infrared transmittances of sodium-lead-silicate glass 26 within range of compositions with increased absorptance at 2.9 microns, $t=2.12 \mathrm{~mm}$.

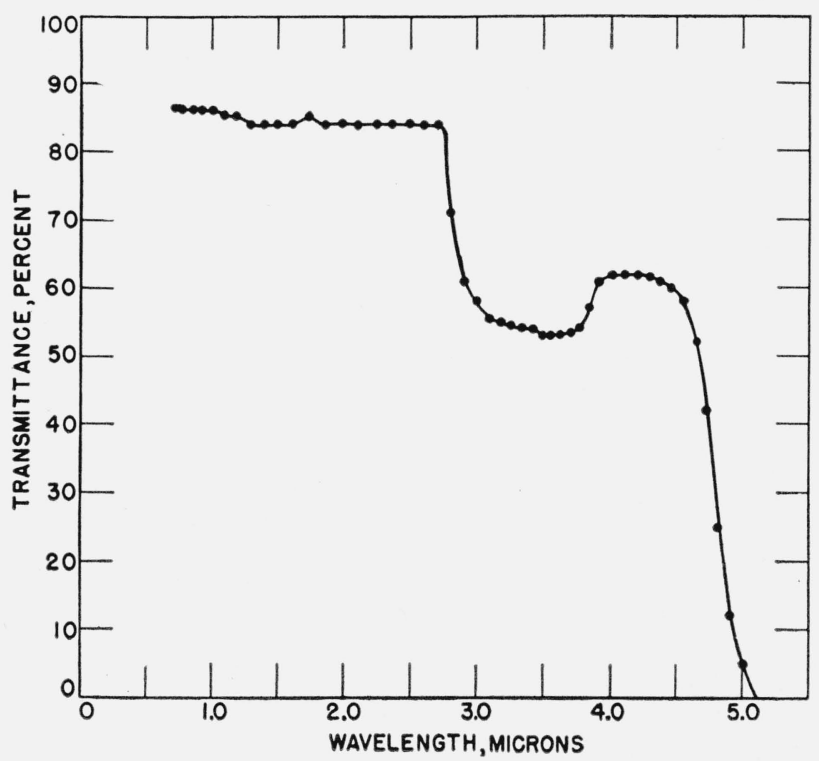

Figure 12. Infrared transmittances of sodium-lead-silicate glass 28 within range of compositions with increased absorptance at 2.9 microns, $t=1.90 \mathrm{~mm}$. 


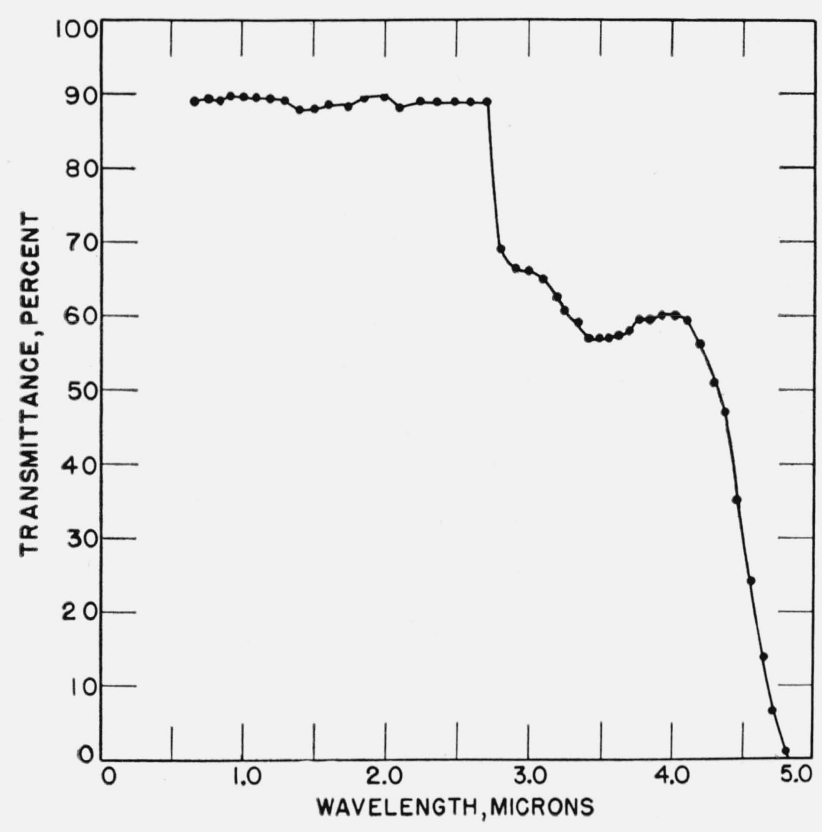

FIGURE 13. Infrared transmittances of sodium-lead-siticate glass 29 within range of compositions with increased absorptance at 2.9 microns, $t=1.84 \mathrm{~mm}$.

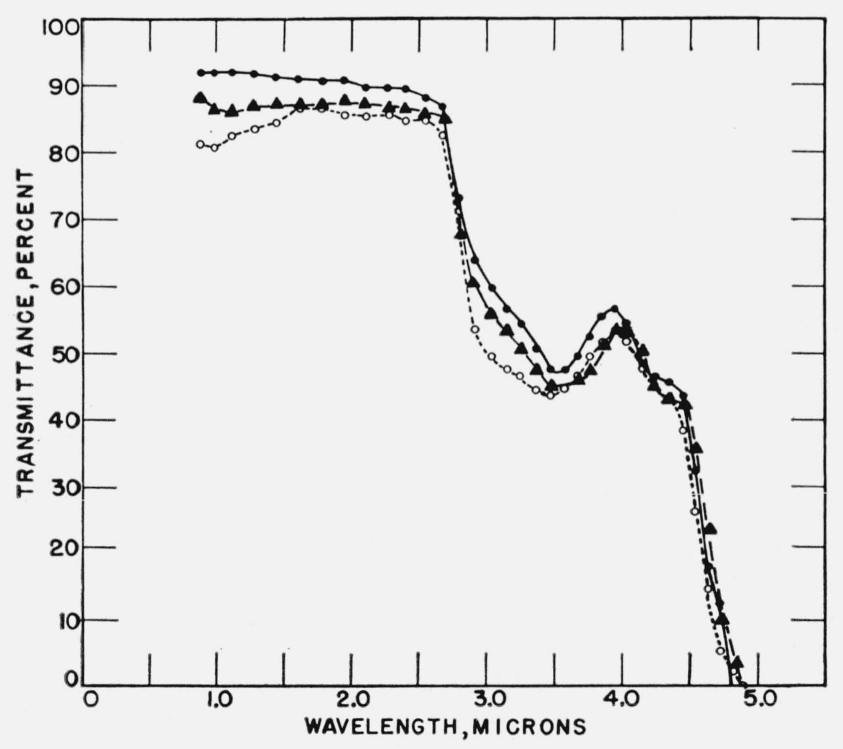

FIGURE 15. Infrared transmittances of lithium-alkali earthsilicate glasses.

, Glass 31 , ealcium oxide, $t=1.82 \mathrm{~mm}$;

Glass 32 , strontium oxide, $t=1.85 \mathrm{~mm}$;

$\boldsymbol{\Lambda}$. Glass 33 , barium oxide, $t=1.80 \mathrm{~mm}$.

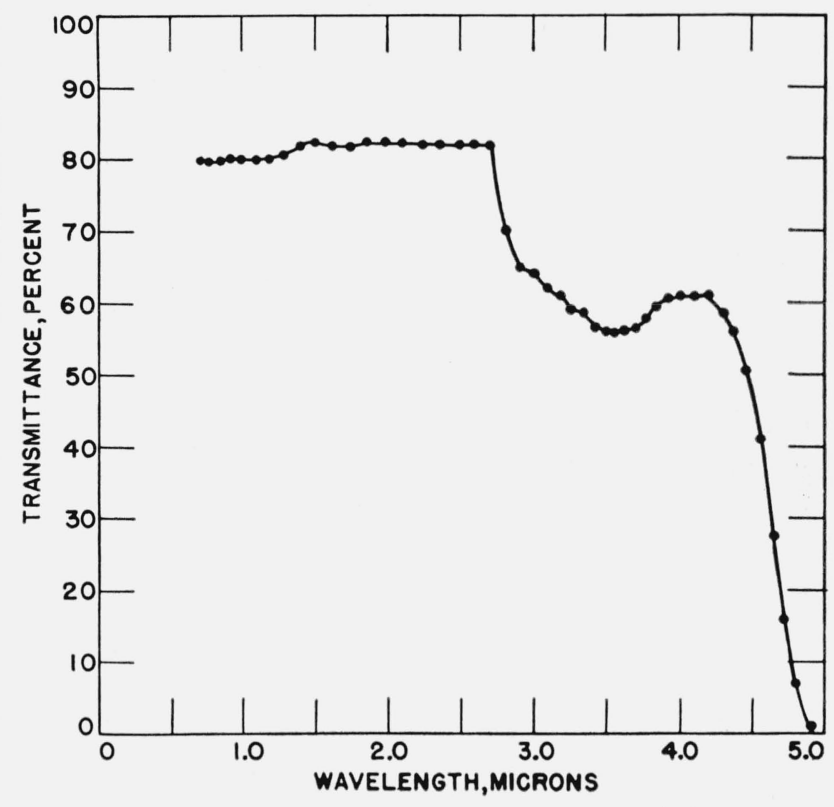

FIGURE 14. Infrared transmittances of sodium-lead-silicate glass 30 within range of compositions with increased absorptance at 2.9 microns, $t=1.84 \mathrm{~mm}$.

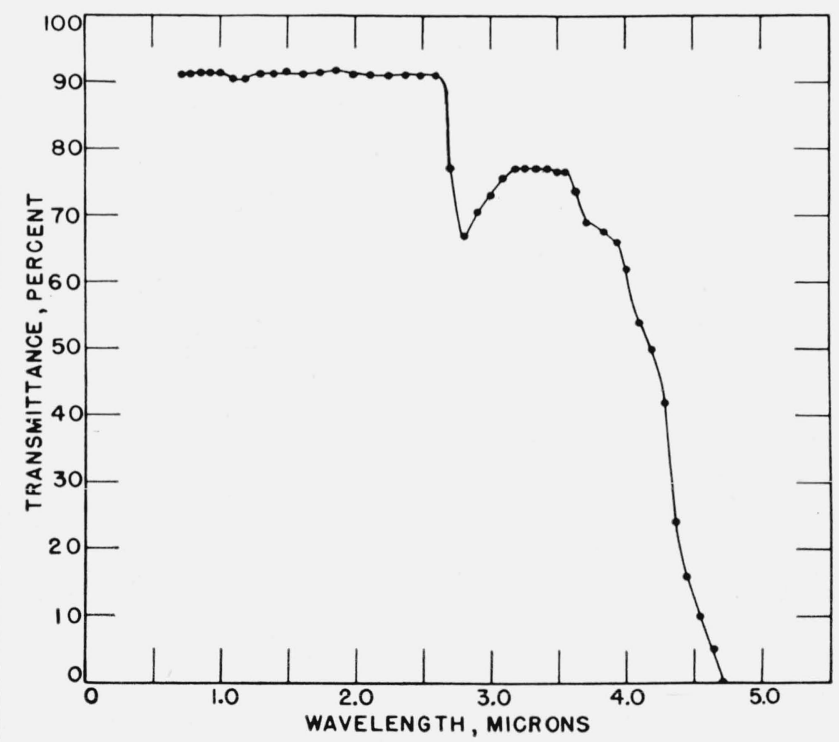

FiguRE 16. Infrared transmittances of low-expansion, lithiumberullium-silicate glass $34, t=2.23 \mathrm{~mm}$. 


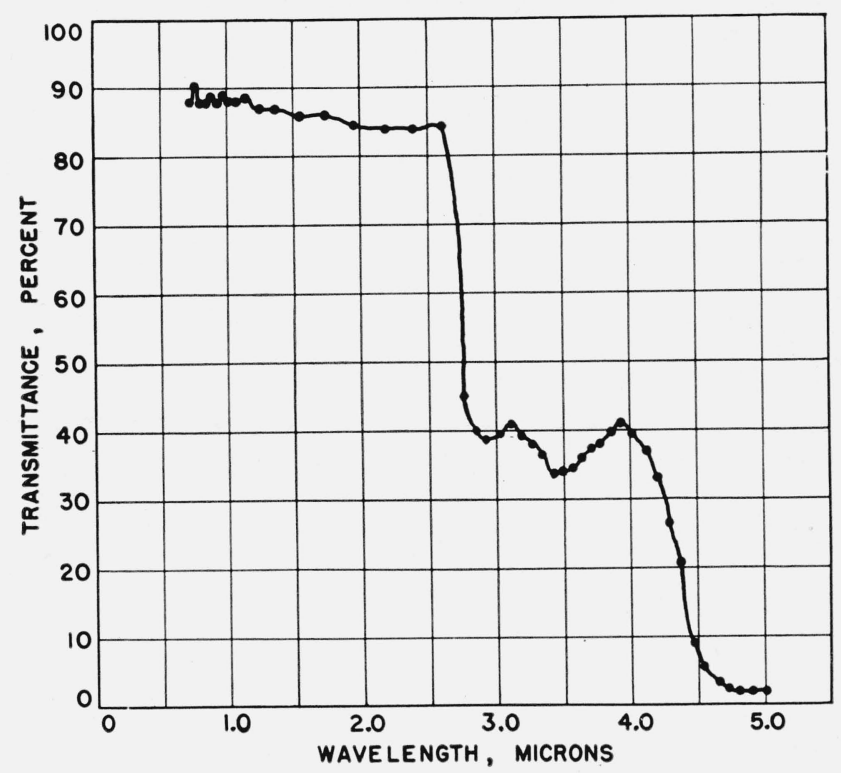

FIGURE 17. Infrared transmittances of sodium-berylliumsilicate glass, No. $35, t=2.10 \mathrm{~mm}$.

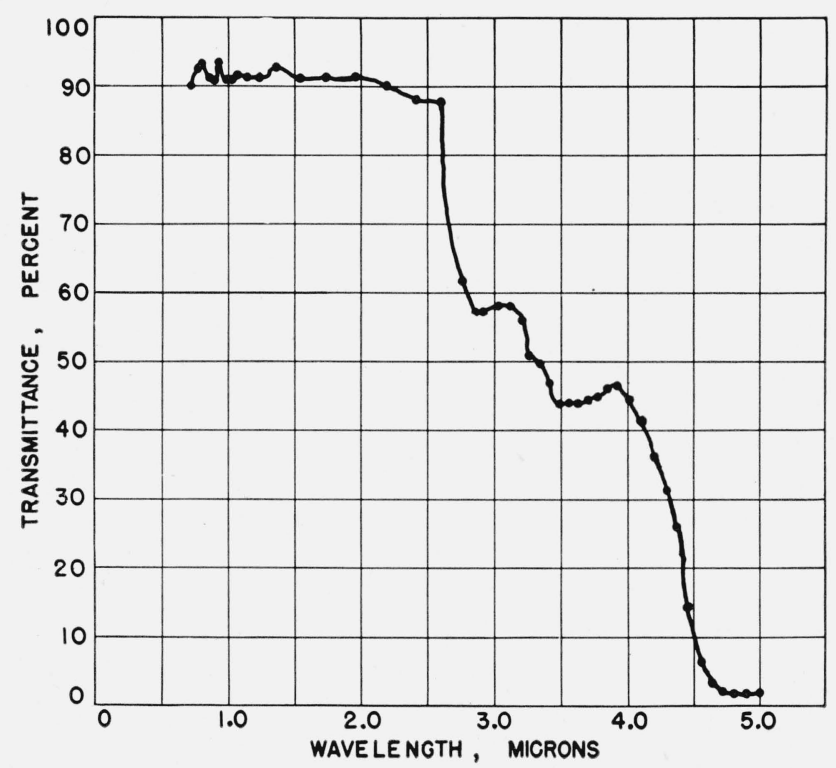

Figure 19. Infrared transmittances of sodium-calciumsilicate glass $3 \%, t=2.14 \mathrm{~mm}$.

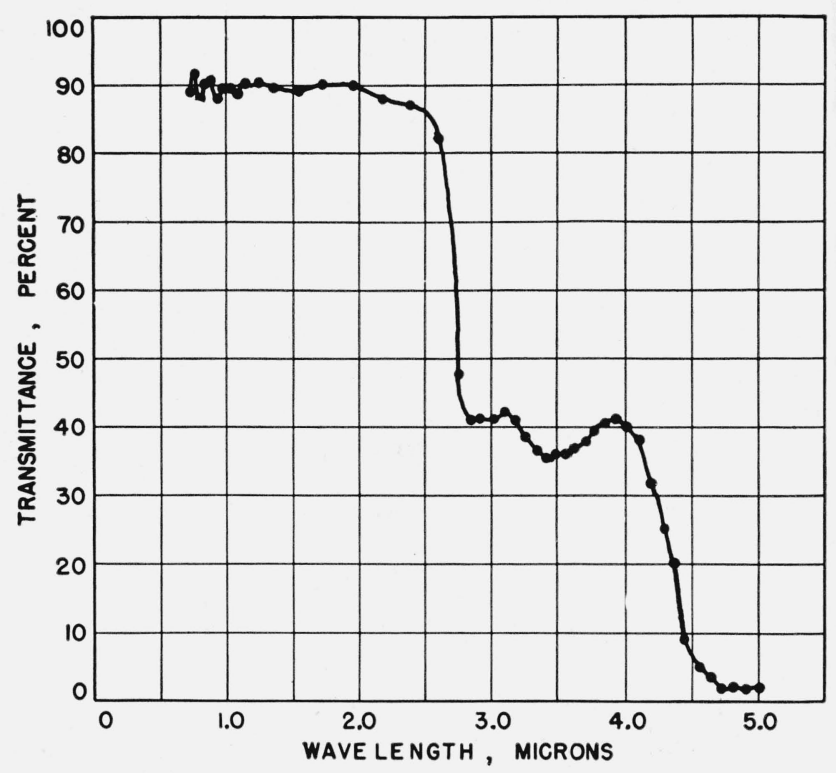

FIGURE 18. Infrared transmittances of sodium-magnesiumsilicate glass $36, t=2.16 \mathrm{~mm}$.

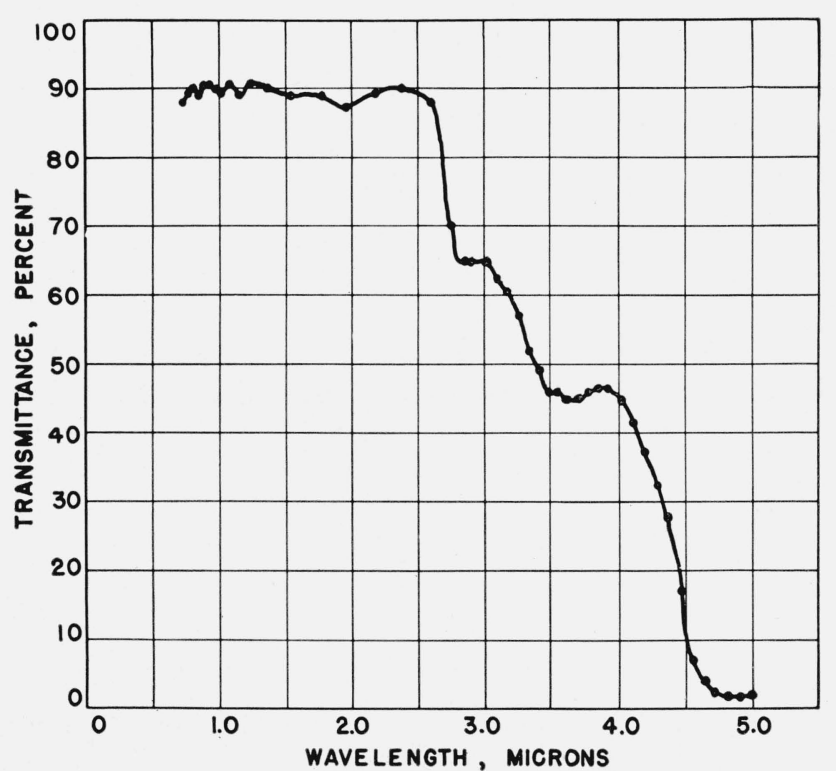

FIGURE 20. Infrared transmittances of sodium-strontium silicate glass $38, t=2.07 \mathrm{~mm}$. 


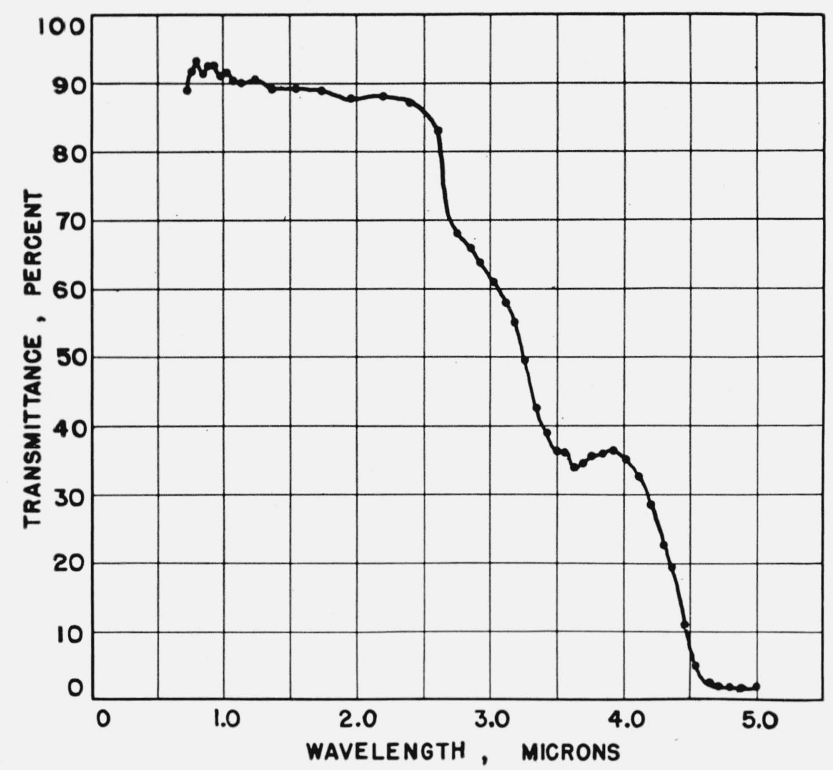

FIgure 21. Infrared transmittances of sodium-barium-silicate glass $39, t=2.19 \mathrm{~mm}$.

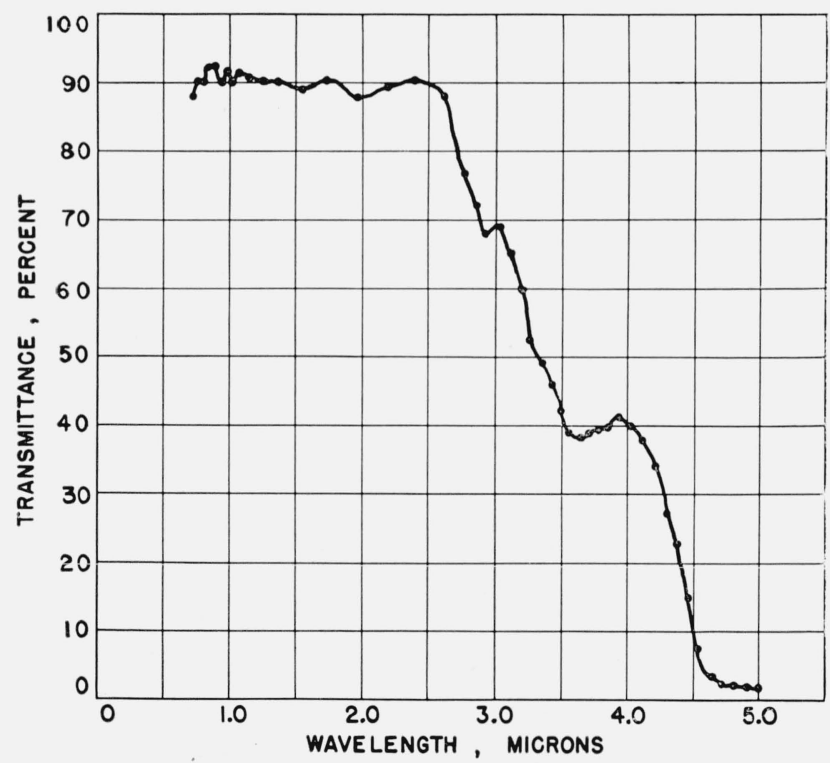

FIGURE 23. Infrared transmittances of potassium-strontiumsilicate glass $41, t=2.09 \mathrm{~mm}$.

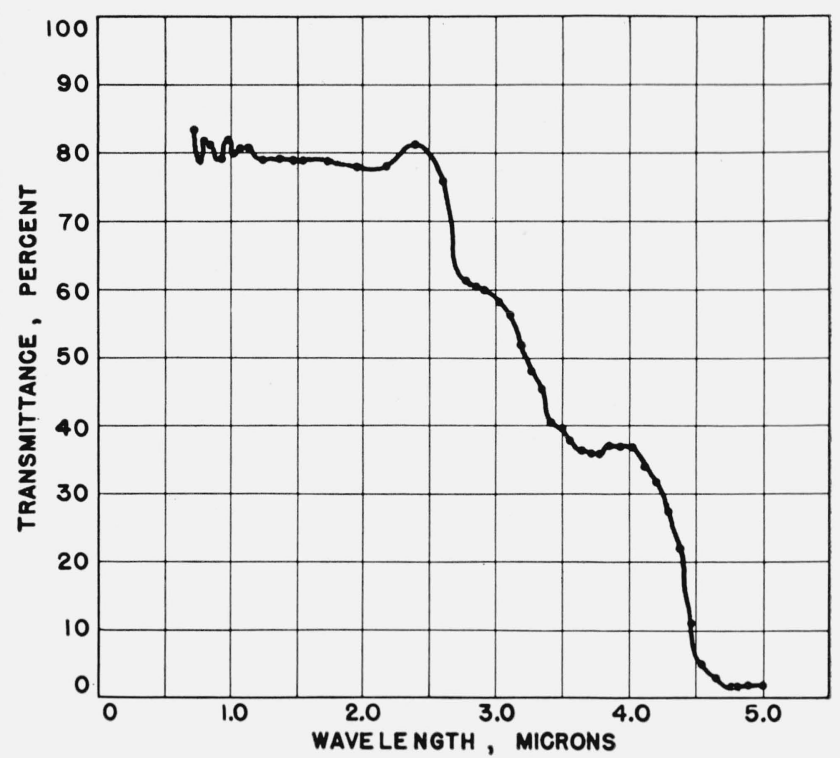

FIGURE 22. Infrared transmittances of potassium-calciumsilicate glass $40, t=2.19 \mathrm{~mm}$.

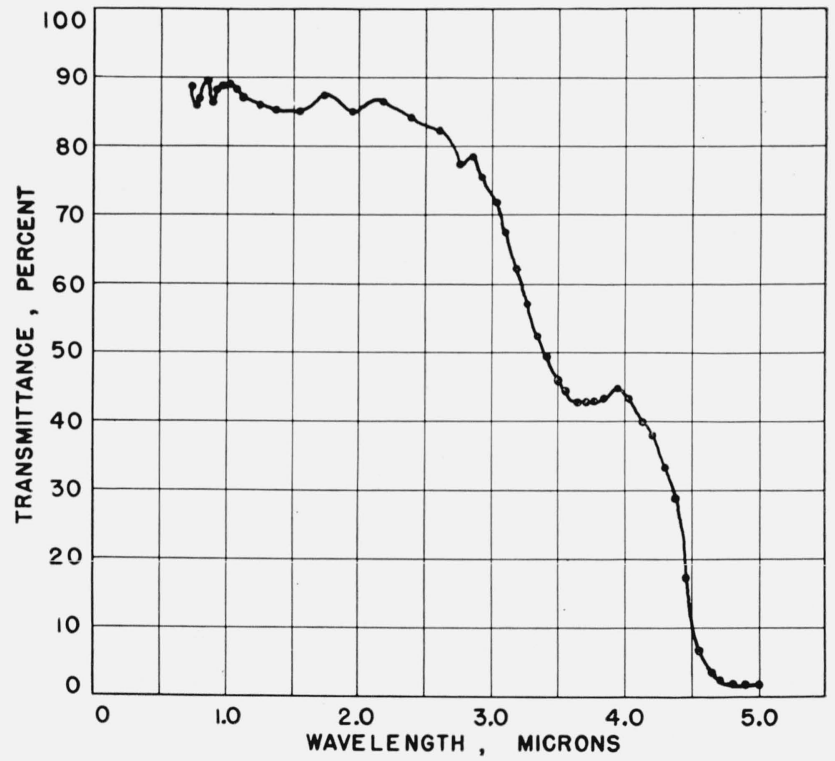

FIGURE 24. Infrared transmittances of potassium-bariumsilicate glass $42, t=2.07 \mathrm{~mm}$. 


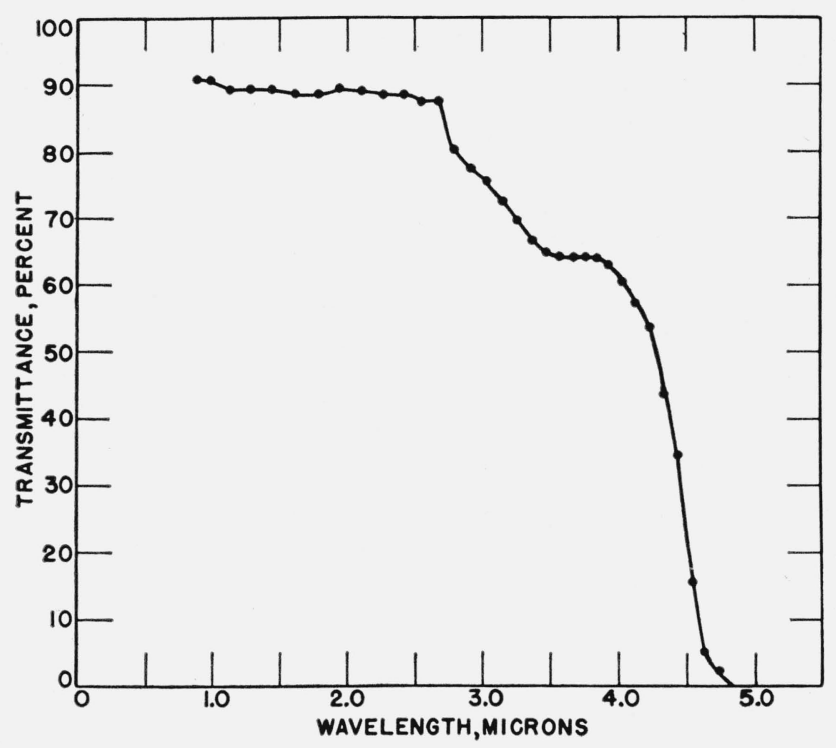

Figure 25. Infrared transmittances of barium-lead-silicate glass $43, t=2.00 \mathrm{~mm}$.

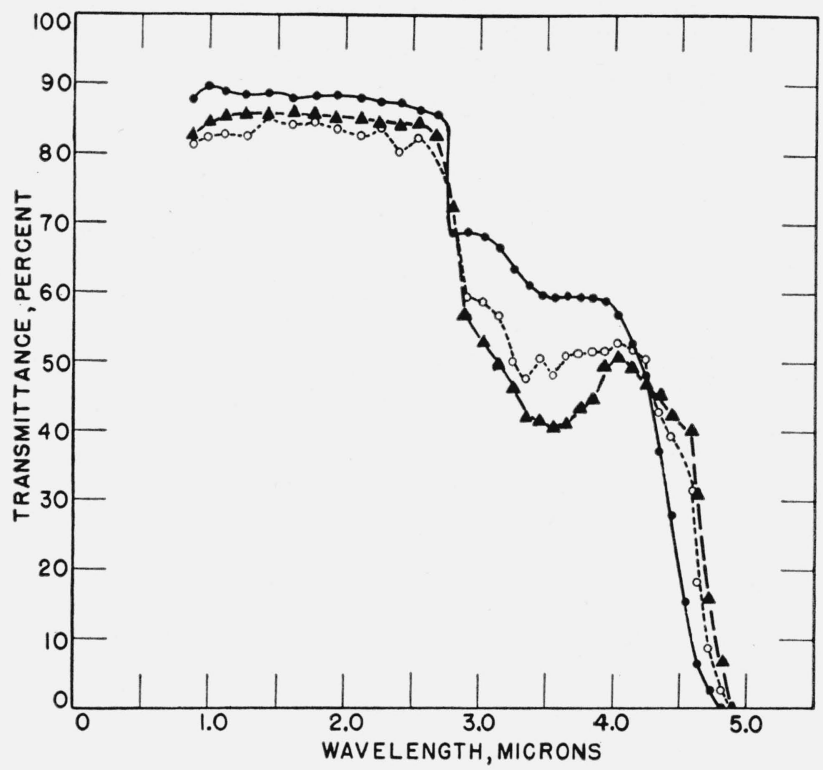

FIGURE 26. Infrared transmittances of additional bariumlead-silicaie glasses indicating that composition is critical for maximum transmissivity.

-, glass 44, $t=2.04 \mathrm{~mm}$; $\bigcirc$, glass $45, t=1.52 \mathrm{~mm}$; $\mathbf{\Lambda}$, glass $46, t=2.23 \mathrm{~mm}$.

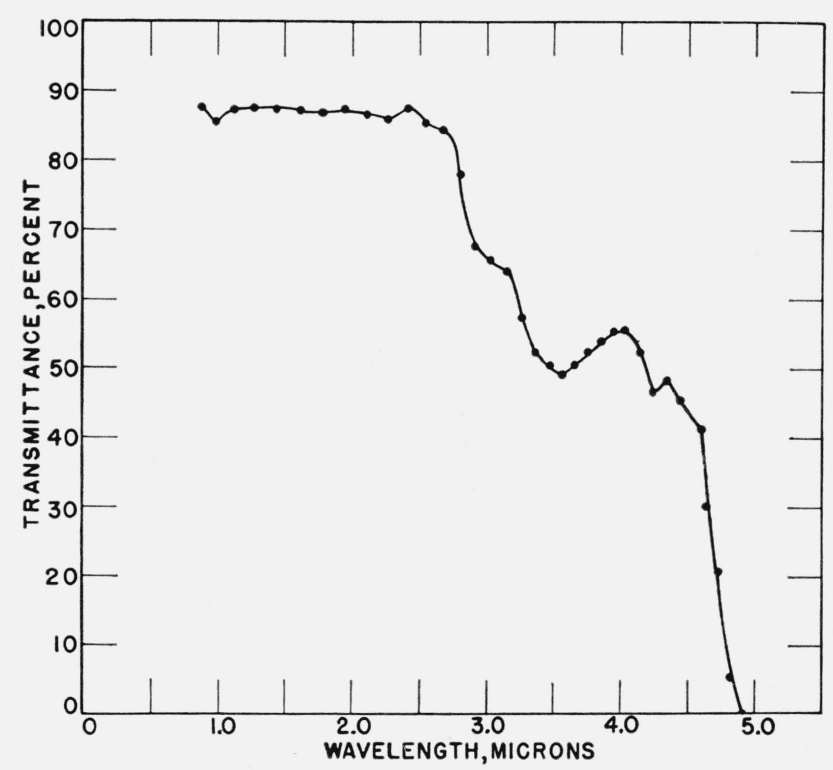

FIGURE 27. Infrared transmittances of calcium-barium-silicate glass $4 \%, t=1.56 \mathrm{~mm}$.

Washington, D. C., February 27, 1953. 